\title{
Peran Antagonis Reseptor H-2 Dalam Pengobatan Ulkus Peptikum
}

\author{
Noval Aziz
}

\begin{abstract}
Ulkus peptikum adalah kerusakan pada lapisan mukosa, submukosa sampai lapisan otot saluran cerna yang disebabkan oleh aktivitas pepsin dan asam lambung yang berlebihan. Ulkus peptikum dapat bersifat primer (akut dan kronis) atau sekunder akibat adanya penyakit lain. Tujuan utama pengobatan ulkus peptikum adalah untuk mengurangi rasa sakit, mempercepat penyembuhan ulkus dan mencegah terjadinya residif ataupun komplikasi. Antagonis reseptor $\mathrm{H}_{2}$ berperan dalam mengurangi sekresi asam lambung dengan menghambat pengikatan histamin secara selektif pada reseptor $\mathrm{H}_{2}$ dan menurunkan kadar cyclic-AMP dalam darah. Antagonis reseptor $\mathrm{H}_{2}$ yang paling banyak digunakan pada kelompok anak sebagai pengobatan standar terhadap ulkus peptikum adalah simetidin dan ranitidin. Simetidin dan ranitidin efektif untuk menghilangkan gejala nyeri pada episode akut dan mempercepat penyembuhan ulkus dengan toksisitas relatif ringan. Pada kasus ulkus peptikum kronik yang disertai infeksi oleh Helicobacter pylori, diperlukan pemberian antibiotik amoksisilin dan atau metronidazol.
\end{abstract}

Kata kunci: ulkus peptikum - antagonis reseptor $\mathrm{H}-2$.

U

lkus peptikum (UP) adalah kerusakan pada lapisan mukosa, sub mukosa sampai lapisan otot saluran cerna yang disebabkan oleh aktifitas pepsin dan asam lambung. Ulkus peptikum dapat mengenai esofagus sampai usus halus, tetapi kebanyakan terjadi pada bulbus duodenum (90\%) dan kurvatura minor. ${ }^{1,2}$ Bila terjadi di antara kardia dan pilorus disebut ulkus lambung dan bila terjadi pada daerah setelah pilorus disebut ulkus duodenum. ${ }^{3}$

Ulkus peptikum sangat jarang terjadi pada bayi dan anak dibanding dewasa, namun insiden yang pasti belum diketahui. ${ }^{4,5}$ Pada kelompok anak, usia yang paling sering dikenai adalah 12-18 tahun; laki-laki lebih banyak dibanding perempuan. ${ }^{5,6}$

Patogenesis UP beragam dan belum diketahui seluruhnya. ${ }^{2,6}$ Umumnya terjadi akibat sekresi asam yang berlebihan dan gangguan ketahanan / integritas

Alamat korespondensi:

Dr. Noval Aziz, Sp.A.

Bagian Ilmu Kesehatan Anak Fakultas Kedokteran Universitas Sumatera Utara/ RSUP Haji Adam Malik. Jl. Bunga Lau No. 17. Medan.

Telepon 836 0405, 836 0143, 836 034. Fax. 8361721. mukosa, sehingga terjadi difusi balik ion $\mathrm{H}^{+}$dari lumen usus masuk ke dalam mukosa. , 3,5-7 $^{\text {Mekanisme }}$ keseimbangan antara faktor agresif (perusak) dan faktor defensif (ketahanan mukosa) sangat penting untuk mempertahankan fungsi dan integritas saluran cerna. Faktor agresif yang utama adalah asam lambung dan pepsin. Faktor defensif yang berperan adalah mucous barrier (mukus dan bikarbonat), mucosal resistance barrier (resistensi mukosa), microcirculation (aliran darah mukosa) dan prostaglandin. ${ }^{7}$

Klasifikasi UP yang sering digunakan dibuat oleh Schuster dan Gross (1963) yaitu ulkus peptikum primer dan sekunder. ${ }^{1}$ Ulkus peptikum primer adalah ulkus yang terjadinya terutama dipengaruhi langsung oleh sekresi asam lambung dan pepsin yang berlebihan. ${ }^{1,4}$ Ulkus peptikum primer dapat bersifat akut dan kronis, dibedakan berdasarkan pemeriksaan histologi. Ulkus peptikum primer akut menunjukkan gambaran proses erosi dengan tepi tajam, tidak ada kongesti, hanya dijumpai tanda inflamasi minimal di sekitar ulkus dan dalam penyembuhannya tidak disertai fibrosis. Pada ulkus peptikum primer kronis ditemukan jaringan nekrotik dengan dasar eksudat fibropurulen dan jaringan 


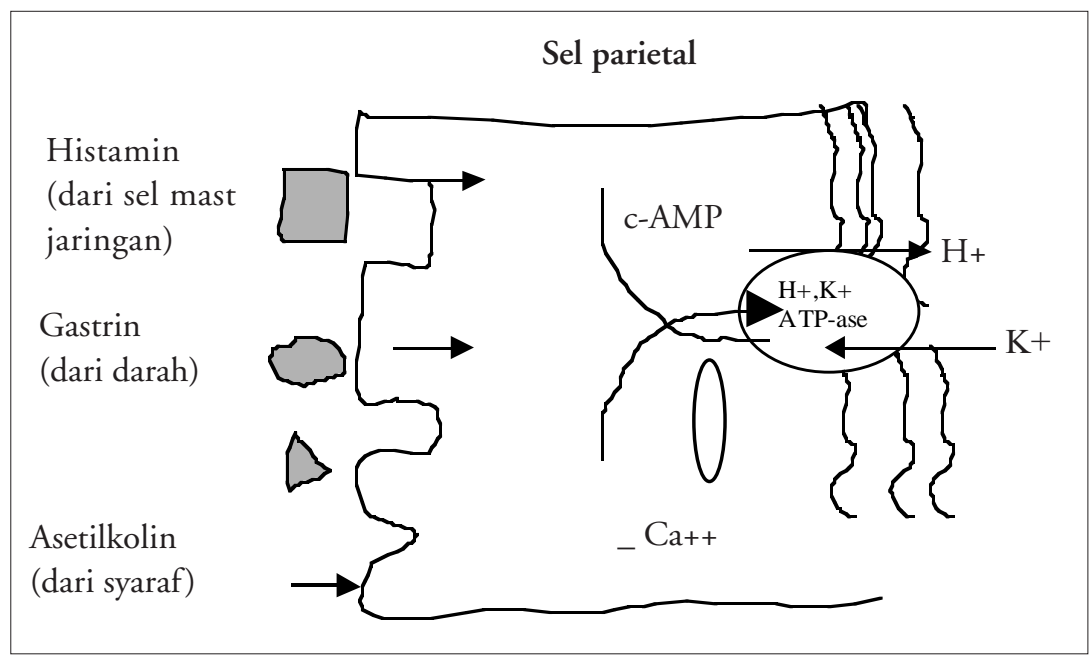

Gambar 1. Model sederhana dari sel parietal, $H 2$ = histamin, $G=$ gastrin, $M 2$ = reseptor a setilkolin / muskarinik ${ }_{2}^{13}$ Histamin meningkatkan konsentrasi c-AMP intrasesular, sementara gastrin dan asetilkolin meningkatkan kalsium intraselular.

granulasi vaskular dengan pembentukan fibrosis. Pada permukaan jaringan nekrotik tersebut sering ditemukan Helicobacter pylori. ${ }^{1}$ Ulkus peptikum sekunder didasarkan adanya gangguan ketahanan mukosa saluran cerna, yang dapat terjadi setelah mengalami penyakit/ trauma berat (stress ulcer), luka bakar (Curling's ulcer), penyakit intrakranial (Rokitansky-Cushing's ulcer), minum aspirin atau kortikosteroid, dan penyakit hati kronis. ${ }^{1,3,4,8}$

Diagnosis UP dapat ditegakkan berdasarkan anamnesis, pemeriksaan radiologis dan dipastikan dengan pemeriksaan endoskopi. ${ }^{17,8}$ Ulkus peptikum pada anak sering menunjukkan gejala muntah, nyeri perut yang bersifat periodik dan dipicu dengan masuknya makanan, dalam keadaan berat dapat terjadi perdarahan. ${ }^{1,8}$ Gejala klinis UP pada anak dapat menyerupai gejala esofagitis, penyakit hati dan saluran empedu, pneumonia, pankreatitis, atau giardiasis. ${ }^{8}$

Meskipun UP merupakan penyakit dengan angka kematian relatif rendah. Pengobatan UP telah banyak dikembangkan, yaitu istirahat, diet, netralisasi keasaman lambung (antasida), antikolinergik, antagonis reseptor $\mathrm{H}-2$ (ARH-2), inhibitor pompa proton, obat sitoprotektif, prostaglandin dan operasi pada kasus dengan perdarahan berat. ${ }^{7}$ Kaitan aktivitas asam lambung yang berlebihan dengan kejadian UP memungkinkan penggunaan obat untuk mengurangi produksi asam lambung menjadi salah satu pilihan penting dalam pengobatan UP. Tujuan tulisan ini untuk memberi gambaran secara umum peranan antagonis reseptor $\mathrm{H}-2$ dalam pengobatan UP.

Pada awalnya patogenesis UP dikaitkan dengan faktor stres dan makanan, sehingga pengobatan diutamakan pada istirahat di rumah sakit dan pemberian makanan lunak. ${ }^{9}$ Namun tidak ada bukti yang mendukung bahwa istirahat dan mengkonsumsi makanan lunak berpengaruh pada lamanya penyembuhan ulkus. ${ }^{1,6}$ Kemudian konsep UP didasarkan pada sekresi asam lambung yang berlebihan, dengan pengobatan utama menggunakan antasid. ${ }^{9}$ Antasid dapat mengurangi nyeri, namun hanya bersifat sementara. ${ }^{1}$ Netralisasi asam lambung oleh antasida tergantung pada komposisi dan dosis, ada tidaknya makanan, dan adanya mukoprotein atau subtansi lain dalam lambung. ${ }^{12}$ Netralisasi keasaman lambung dengan pemberian bahan alkali sangat sulit dicapai tanpa menyampingkan timbulnya efek samping. Pemberian antasid tunggal untuk mengobati UP pada anak tidak efektif, ${ }^{2,11,12}$ dan penggunaan jangka panjang untuk pencegahan UP tidak dianjurkan. ${ }^{12}$ Dosis terapeutik antasid yang dibutuhkan pada UP relatif besar dan harus diberikan 1 dan 3 jam setelah makan dan saat tidur, sehingga menimbulkan ketidaknyamanan bagi pasien. ${ }^{2,4,8,11}$

Dasar pengobatan UP berkembang dengan ditemukannya penghambat sekresi asam lambung, seperti antagonis muskarinik (antikolinergik), ARH2, dan penghambat pompa proton. ${ }^{7}$ Reseptor $\mathrm{H}-2$, sebuah subtipe reseptor histamin, ditemukan oleh Sir James Black pada tahun 1971, sebagai mediator 
penting dalam asam lambung. ${ }^{9}$ Reseptor histamin berada pada lapisan basolateral dan sel parietal. Adanya histamin pada reseptor H-2 akan mengaktifasi adenilsiklase dan terjadi peningkatan konsentrasi cyclicadenosin monophosphate (c-AMP) intraselular. Peningkatan konsentrasi c-AMP mengaktifasi pompa proton (hidroksida kalium ATP-ase) pada sel parietal untuk mensekresi ion hidrogen $(\mathrm{H}+)$ menggantikan posisi ion kalium $(\mathrm{K}+)^{12,13}$

ARH-2 secara selektif dan kompetitif menghambat pengikatan histamin pada reseptor $\mathrm{H}-2$, selanjutnya menurunkan konsentrasi c-AMP dan menurunkan sekresi ion hidrogen pada sel parietal. ${ }^{12}$ Secara struktural ARH-2 tidak menyerupai antagonis reseptor H-1, sehingga relatif tidak mempengaruhi efek penghambatan pada reseptor $\mathrm{H}-1$ ataupun reseptor autonomik. ${ }^{11,12,14}$

Ada 4 jenis ARH-2 yang dikenal, yaitu: simetidin, ranitidin, famotidin dan nizatidin. ${ }^{8,15,16}$ Simetidin merupakan senyawa antagonis reseptor pertama yang ditemukan, yang mengandung cincin imidazol dari histamin. Pada penemuan selanjutnya cincin imidazol digantikan dengan senyawa furan (ranitidin) dan senyawa tiazol (famotidin dan nizatidin) (Gambar 2). ${ }^{13}$

Sekresi asam lambung basal normal rata-rata 2-4 $\mathrm{mEq} /$ jam dengan dosis standar ARH-2 dapat menurunkan sekresi asam lambung hingga $60-70 \%$. Pada dosis yang sesuai semua jenis ARH-2 mempunyai efikasi yang hampir sama, tetapi secara farmakodinamik simetidin dan ranitidin memiliki sifat lebih baik dan merupakan pilihan pertama pada pengobatan UP pada anak. ${ }^{4,6,15,17}$

\section{Peran ARH-2 pada pengobatan UP}

Tujuan utama pengobatan UP untuk mengurangi rasa sakit, penyembuhan ulkus dan mencegah terjadinya residif dan komplikasi. ${ }^{2,4}$ ARH-2 menurunkan volume cairan lambung dan konsentrasi $\mathrm{H}^{+}$. Penurunan sekresi oleh sel kelenjar lambung berlangsung simultan dengan penurunan volume cairan lambung. ${ }^{12}$ ARH-2 dapat menurunkan sekresi asam lambung basal (puasa), nokturnal, dan post-prandial atau yang distimulasi oleh insulin. ${ }^{1,12,16}$ Penghambatan sekresi asam lambung nokturnal merupakan faktor penting pada penyembuhan UP, sehingga penggunaan satu dosis pada malam hari menjelang tidur sangat bermanfaat. ${ }^{12,15,16}$

\section{Pengobatan UP primer}

Pemberian susu atau antasida dengan interval pendek dapat menghilangkan gejala ulkus duodenum bila diminum secara teratur dalam waktu 1-2 bulan pengobatan, namun hal ini selalu disertai dengan

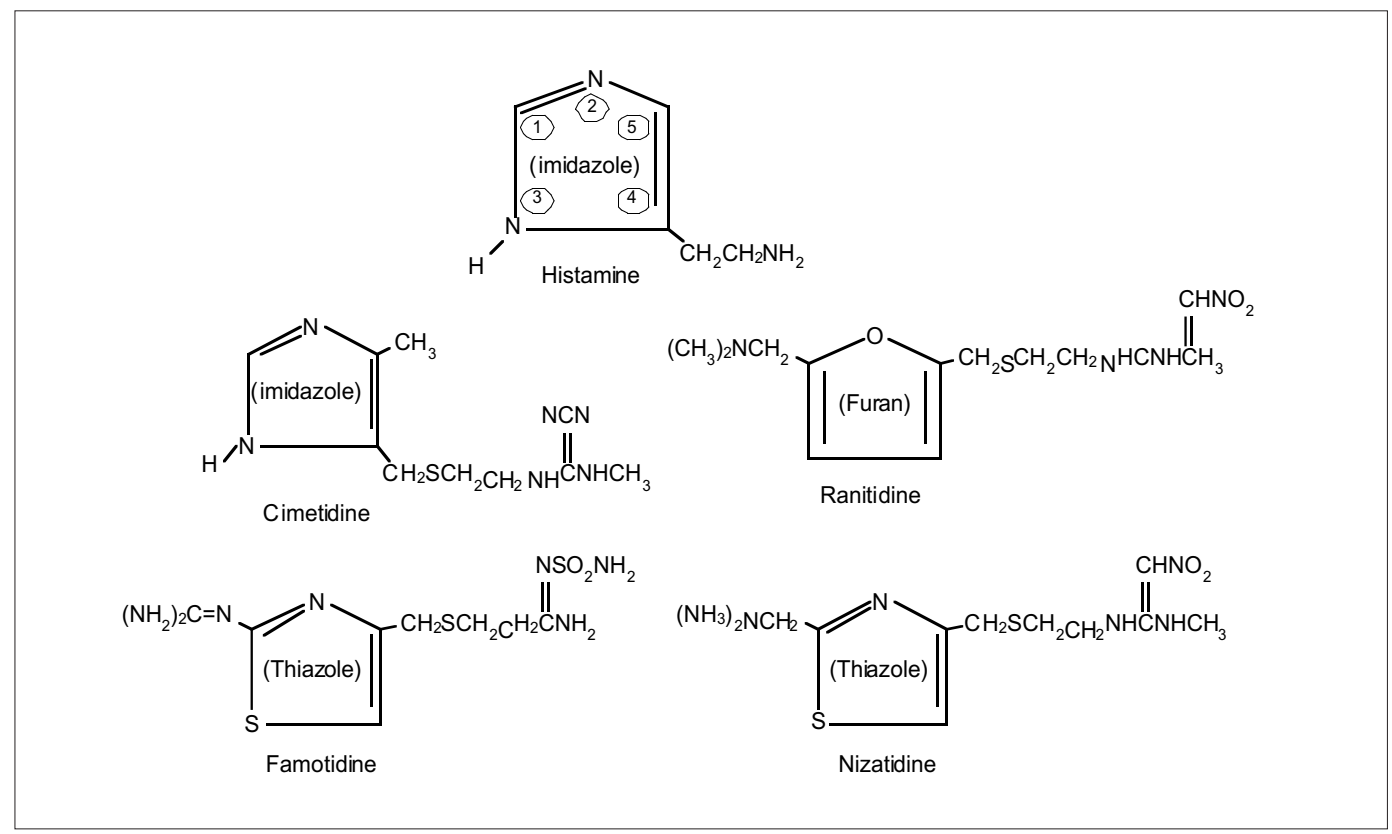

Gambar 2. Struktur kimia histamin dan 4 jenis ARH-2 $2^{13}$ 
timbulnya efek samping. ${ }^{1}$ Simetidin atau ranitidin memiliki potensi untuk menekan sekresi asam hidroklorida pada kasus ulkus duodenum, menghilangkan gejala selama episode akut dan mempercepat penyembuhan ulkus dengan toksisitas relatif ringan. ${ }^{11,16}$ Dosis yang dianjurkan untuk kelompok anak adalah $20-40 \mathrm{mg} / \mathrm{kgbb} / \mathrm{hari}$ terbagi dalam 4 dosis untuk simetidin dan 4-6 mg/kgbb/hari terbagi dalam 2 dosis untuk ranitidin. ${ }^{4}$

Penggunaan ARH-2 pada UP dapat menyembuhkan ulkus dalam pengobatan selama 4-6 minggu dan kadangkadang hingga 8 minggu dengan tingkat penyembuhan 84-97\%. ${ }^{16}$ Pada 10\% kasus ulkus duodenum dibutuhkan waktu pengobatan lebih lama dan kadang-kadang diperlukan antasid dosis tinggi. ${ }^{18}$ Beberapa pasien memerlukan terapi jangka panjang untuk mencegah relaps dan komplikasi, dengan pemberian sekali sehari setengah dosis awal. ${ }^{11,19}$

Setelah masa penyembuhan, 50\% kasus ulkus duodenum mengalami relaps dalam 1 tahun dan keadaan ini dapat diturunkan hingga 25\% dengan pemberian ARH-2 dosis satu kali sehari menjelang tidur. ${ }^{18}$ Tidak ada perbedaan relaps pada penggunaan ranitidin dan simetidin. Faktor yang mempengaruhi relaps umumnya adalah merokok, lama dan berat penyakit, genetik dan infeksi Helicobacter pylori. ${ }^{1}$

Pada kasus ulkus duodedum kronik, perlu dipikirkan adanya infeksi Helicobacter pylori, dan pengobatan terhadap anggota keluarga lain untuk menekan sumber infeksi. ${ }^{1,19}$ Delapan puluh lima persen kasus ulkus duodenum kronik pada anak terbukti berkaitan dengan adanya infeksi Helicobacter pylori. ${ }^{8}$ Pada kasus UP dengan infeksi Helicobacter pylori, pemberian ARH-2 saja tidak dapat menyembuhkan, meskipun dapat menghilangkan rasa nyeri. Dibutuhkan pemberian antibiotik amoksisilin dan metronidazol, minimal selama 2 minggu. ${ }^{1,5,7}$ Ulkus peptikum dengan infeksi Helicobacter pylori yang hanya diobati dengan ARH-2 saja, 90\% mengalami relaps dalam waktu 1 tahun. ${ }^{4}$ Telah dibuktikan bahwa efikasi gabungan ranitidin, amoksisilin dan metronidazol dalam pengobatan UP mencapai $90 \%{ }^{9}$

Meskipun memiliki potensi kuat dalam menekan sekresi asam lambung, penggunaan obat-obat antagonis muskarinik (misalnya pirenzepin) tidak direkomendasikan pada ulkus duodenum pada anak, baik sebagai pengobatan awal ataupun pencegahan. ${ }^{1,4,6,8,10}$ Antagonis muskarinik dapat menghambat sekresi asam lambung pada dosis yang menimbulkan efek samping berupa mulut kering dan mata kabur. ${ }^{4}$

Obat sitoprotektif bismut koloidal banyak digunakan pada kasus UP kronik dengan infeksi Helicobacter pylori, ${ }^{1}$ dikombinasi dengan gabungan tetrasiklin dan metronidazol atau amoksisilin dan klaritromisin. ${ }^{14}$ Selain sebagai pelindung selektif di atas dasar ulkus pada $\mathrm{pH}$ asam dan sebagai sawar terhadap difusi asam lambung, pepsin dan asam empedu, bismut koloidal juga bersifat bakterisidal terhadap Helicobacter pylori. Di sisi lain bismut koloidal bersifat nefrotoksik, menimbulkan pewarnaan hitam pada gigi, lidah dan feses, serta dapat menyebabkan konstipasi dan melena, sehingga tidak diberikan untuk jangka panjang. ${ }^{7}$ Obat sitoprotektif lainnya, yaitu karbenoksolon, sukralfat dan prostaglandin jarang digunakan pada anak. ${ }^{1}$

Tindakan operasi umumnya dilakukan pada kasus dengan perforasi lambung atau duodenum, perdarahan masif yang tidak dapat diatasi dengan pengobatan standar, obstruksi duodenum atau muara lambung karena jaringan parut, dan kegagalan pengobatan pada kasus hipersekresi asam. 1,5,8,10,19 Food and Drug Administration (FDA) merekomendasikan pemberian simetidin dalam pencegahan perdarahan lambung. ${ }^{16}$

Penggunaan ARH-2 pada ulkus lambung dapat menghilangkan gejala dan mempercepat penyembuhan ulkus. ${ }^{15}$ Pengobatan standar adalah dengan simetidin atau ranitidin. ${ }^{1}$ Dosis yang digunakan sama dengan pada ulkus duodenum, jarang dijumpai relaps pada ulkus lambung yang telah sembuh. ${ }^{1,15}$

\section{Pengobatan UP sekunder}

Pengobatan ulkus sekunder ditujukan pada pengobatan penyakit dasar, disertai pemberian antasid dan ARH2. Pemberian ARH-2 sama dengan pengobatan ulkus primer. ${ }^{8}$ Pada kasus berat, mempertahankan $\mathrm{pH}$ lambung $>3,5$ sangat penting untuk pencegahan pembentukan ulkus. ${ }^{4}$

\section{Pengobatan Zollinger-Ellison syndrome}

Pada beberapa kasus Zollinger-Ellison syndrome, ARH-2 dapat menekan hipersekresi asam lambung yang disebabkan oleh gastrin-secreting tumor; baik pada saat sebelum operasi atau sebagai terapi primer pada kasus yang tidak dioperasi. ${ }^{14,11}$ 


\section{Interaksi dengan obat lain}

Semua jenis antagonis reseptor H-2 dapat mempengaruhi absorbsi obat lain karena efek peningkatan $\mathrm{pH}$ lambung, misalnya ketokonazol, etanol dan bismut. Sebaliknya, adanya obat lain di dalam lambung juga dapat mempengaruhi kerja antagonis reseptor $\mathrm{H}-2$, misalnya magnesium hidroksida dan aluminium hidroksida yang dapat menurunkan bioviabilitas simetidin, ranitidin dan famotidin sampai $30-40 \%$. Oleh karena itu bila antagonis reseptor $\mathrm{H}-2$ diberikan bersama dengan antasid, sebaiknya antasid diberikan minimal 2 jam sebelum atau 2 jam sesudah pemberian antagonis reseptor $\mathrm{H}-2$. Obat lain yang dapat mempengaruhi kerja ARH-2 adalah propantelin (meningkatkan absorbsi ARH-2), metoklopramid (menurunkan absorbsi ARH2), dan fenobarbital (menurunkan absorbsi ARH-2). ${ }^{13}$

\section{Efek samping}

Efek samping ARH-2 biasanya minimal, dan hanya dijumpai pada 1-2\% kasus. ${ }^{11}$ Efek samping terutama berhubungan dengan sistem syaraf sentral, seperti nyeri kepala, letargi, bingung, halusinasi, depresi dan insomnia. Efek samping gastrointestinal yaitu konstipasi atau diare, mulut kering, mual, dan perasaan tidak enak di perut (abdominal discomfort). ${ }^{11,16}$

\section{Kesimpulan}

Berdasarkan patogenesis, pengobatan ulkus peptikum ditujukan untuk menekan faktor-faktor agresif dan atau memperkuat faktor defensif mukosa duodenum. Dalam mengurangi produksi asam lambung ARH-2 merupakan obat standar karena efektivitas, keamanan dan kepraktisan penggunaannya dalam terapi jangka pendek untuk menyembuhkan ulkus, maupun terapi jangka panjang untuk mencegah kambuhnya UP.

\section{Daftar Pustaka}

1. Dodge JA. The Stomach. Dalam: Gracey M, Burke V, penyunting. Paediatric Gastro Enterology and Hepatology.
Edisi ke-3. Boston: Black Well Scientific Publications, 1993. h. 77-94.

2. Djuwantoro D. Diagnosis dan pengobatan tukak peptik. Cermin Dunia Kedokteran 1992; 17: 14-7.

3. Spiro HM. Clinical Gastro Enterology. Edisi ke-2. New York: Macmillan Publishing co.,Inc, 1977.h.292-305.

4. Herbst JJ. Ulcer disease. Dalam: Behrman RE, Kliegman RM, Arvin AM, penyunting. Nelson Textbook of Pediatric. Edisi ke-15. Philadelphia: Saunders, 1996.h.1078-2079.

5. Roy CC, Silverman A, Cozzetto FJ. Pediatric clinical gastroenterology. Edisi ke-2. Saint Louis: Mosby, 1975. h. 155-67.

6. Sondheimer JM, Silverman A. Gastrointestinal tract. Dalam: Hay WW, Groothuis JR, Hayward AR, Lenin MJ, penyunting. Current Pediatric Diagnosis \& Treatment. Edisi ke-12. New Jersey: Appleton \& Lange, 1995. h. 611-3.

7. Soemanto PM, Hirlan, Setiawati A, Hadi S. Penatalaksanaan gastritis dan ulkus peptikum. Pendidikan Kedokteran Berkelanjutan Uji Diri. Jakarta: Yayasan Penerbit IDI, 1993. h. 1-29.

8. Hassall E. Peptic Diseases. Dalam: Rudolf. Pediatric, penyunting. Edisi ke-20. California: Prentice Hall Int, 1996. h. 1087-92.

9. NIH Consensus Development Panel on Helicobacter pylori in peptic ulcer disease. Helicobacter pylori in peptic ulcer disease. JAMA 1994; 272:65-9.

10. Korman MG. Quality of healing in peptic ulcer disease. Are $\mathrm{H}_{2}$ receptor antagonists all we need? Gastroenterol Jpn 1993; 28(suppl 5):168-71.

11. Katzung BG. Basic and clinical pharmacology. Edisi ke5. Norwalk: Appleton \& Lange, 1992. h. 238-9.

12. Brunton LL. Agents for control of gastric acidity and treatment of peptic ulcers. Dalam: Alfred Goodman Gilman. Rall TW, Nies AS, Taylor P, penyunting. The pharmacological basis of therapeutics. Singapore: McGraw-Hill Book Co, 1991. h. 897-902.

13. Feldman M, Burton ME. Histamine,-receptor antagonis standard therapy for acid-peptic disease (first of two parts). The New Engl of Med 1990; 323:1672-755.

14. Katzung BG, Trevor AJ. Examination \& board review pharmacology. Edisi ke-5. 1998. h. 136-449.

15. Robinson M, Stanley-SR. $\mathrm{H}_{2}$-Receptor Antagonis Revisited: Current Role in the treatment of gastro-esophageal reflux disease. URL://www.medscope.com

16. Peroutka JA. Histamine- ${ }_{2}$ receptor antagonists-revisited. Virtual Hospital :P\&T News, 1994,14(12).URL://www.vh.org/ Providers/Publications/PTNews/1994/06.94.html

17. Netchvolodoff CV. Refractory peptic lesions. Postsgraduate medicine 1993; 93:143-63.

18. Soll AH. Medical treatment of peptic ulcer disease. JAMA 1996, 275:622-9.

19. McCarthy DM. Maintenance therapy for peptic ulcer. Who needs it? Gastroenterol Jpn 1993, 28 (Suppl. 5), $172-7$. 